\title{
Solid Phase Synthesis of the Cyclic Peptide Portion of Chlorofusin, an Inhibitor of p53-mdm2 Interactions.
}

John P. Malkinson, Mire Zloh, Mohanad Kadom, Rachel Errington, Paul J. Smith, and Mark Searcey

\section{Supporting Information}

\section{General}

Protected amino acids, Rink amide MBHA resin, HBTU and HOBt were purchased from Novabiochem, Nottingham, UK. 2-\{[(9H-fluoren-9-ylmethoxy)carbonyl $]$ amino $\}$ decanoic acid was prepared according to established methods. Peptide synthesis grade DMF was purchased from Rathburn, Walkerburn, Scotland. All other solvents and reagents were purchased from Aldrich, Gillingham, UK. Solvents were dried according to established practices and were freshly distilled prior to use.

Analytical RP-HPLC was performed on a Vydac $\mathrm{C}_{4}$ Protein column $(250 \mathrm{~mm} \times 4.6$ $\mathrm{mm})$. Separation was achieved using a linear gradient at a flow rate of $1.2 \mathrm{~mL} \mathrm{~min}{ }^{-1}$ effected by a Waters $600 \mathrm{~S}$ controller and 616 pump running solvent $\mathrm{A}(0.1 \%(\mathrm{v} / \mathrm{v})$ TFA), solvent B (0.1\% (v/v) TFA in $90 \%$ (v/v) MeCN); $0 \%$ B to $100 \%$ B over 20 min then $100 \%$ B for 5 min then $100 \%$ B to $0 \%$ B over 7 min (System A). Separation was monitored at $214 \mathrm{~nm}$ by a Waters 486 absorbance detector. Retention and purity were determined using Waters Millennium Chromatography Manager software. Semi-preparative RP-HPLC was performed on a Waters Prep LC C 18 column $(100 \mathrm{~mm} \times 25 \mathrm{~mm})$. Separation was achieved using a linear gradient at a flow rate of $5 \mathrm{~mL} \mathrm{~min}^{-1}$ effected by two Applied Biosystems 200 Solvent Delivery System pumps running $20 \% \mathrm{~B}$ to $60 \% \mathrm{~B}$ over $90 \mathrm{~min}$ then $60 \% \mathrm{~B}$ to $100 \% \mathrm{~B}$ over $30 \mathrm{~min}$ (System B). Separation was monitored at $214 \mathrm{~nm}$ by an Applied Biosystems 783A Programmable Absorbance Detector.

Mass spectra were recorded on a Finnigan MassLab Navigator quadrupole instrument using electrospray (ES) ionisation, or an Applied Biosystems Voyager-DE Pro Biospectrometry Workstation using $\alpha$-cyano-4-hydroxycinnamic acid matrix assisted laser desorption ionisation - time-of-flight (MALDI-TOF) mass spectrometry.

\section{Peptide Synthesis}

Peptide synthesis was accomplished manually using a stepwise solid-phase procedure. All couplings were carried out for $20 \mathrm{~min}$ in DMF using a 2.5-fold excess (over resin loading) of protected amino acid, activated with an equimolar amount of HBTU and $\mathrm{HOBt}$, in the presence of a 5-fold excess (over resin loading) of DIEA. Each coupling was repeated and completion monitored using the Kaiser test for free amines. Unsuccessful couplings were further repeated until a negative Kaiser test was obtained. $N^{\alpha}$-Fmoc protection was removed using $20 \%(\mathrm{v} / \mathrm{v})$ piperidine in DMF $(2 \times$ $10 \mathrm{~min})$. Side-chain protecting groups used were tert-butyl for threonine, tertbutoxycarbonyl for ornithine and trityl for D-asparagine.

\section{Cyclisation}

Head-to-tail cyclisation was carried out on the solid-phase. $C$-terminal $4-\{[1-(4,4-$ dimethyl-2,6-dioxocyclohexylidene)-3-methylbutyl]amino\}benzyl (Dmab) protection was removed using $2 \%(\mathrm{v} / \mathrm{v})$ hydrazine hydrate in DMF $(3 \times 3 \mathrm{~min})$. The resin-bound peptide was washed with $5 \%(\mathrm{v} / \mathrm{v})$ DIEA in DMF, then treated with a 3-fold excess (over resin loading) of DIC and HOAt in DMF $(2 \times 24 \mathrm{~h})$. To ensure completion of 
cyclisation (Kaiser test), the resin was further treated with a 3-fold excess each of PyBOP, HOAt and DIEA in DMF for $4 \mathrm{~h}$.

\section{Peptide Cleavage and Isolation}

The resin-bound cyclic peptide was washed thoroughly with $\mathrm{DMF}, \mathrm{CH}_{2} \mathrm{Cl}_{2}$ then $50 \%$ (v/v) $\mathrm{MeOH}$ in $\mathrm{CH}_{2} \mathrm{Cl}_{2}$, and dried in vacuo over $\mathrm{KOH}$ to constant weight. The peptide was removed from the solid support with simultaneous side-chain deprotection by acidolysis using TFA containing $2.5 \%(\mathrm{v} / \mathrm{v})$ water and $2.5 \%(\mathrm{v} / \mathrm{v})$ triisopropylsilane for $2 \mathrm{~h}$ at $25^{\circ} \mathrm{C}$. The TFA was removed under reduced pressure and the crude peptide precipitated and washed with cold anhydrous diethyl ether, then extracted into $50 \%$ (v/v) acetic acid and lyophilised.

ES MS for $2\left(\mathrm{C}_{46} \mathrm{H}_{82} \mathrm{~N}_{12} \mathrm{O}_{13}\right) \quad 1010.6124 \mathrm{~m} / z(\%)$ : $1011.7[\mathrm{M}+\mathrm{H}]^{+}$(100), 1033.7 $[\mathrm{M}+\mathrm{Na}]^{+}(47)$. HPLC retention time $=13.550 \mathrm{~min}($ System $\mathrm{A})$.

ES MS for $3\left(\mathrm{C}_{46} \mathrm{H}_{82} \mathrm{~N}_{12} \mathrm{O}_{13}\right)$ 1010.6124 m/z (\%): $1011.7[\mathrm{M}+\mathrm{H}]^{+}(100), 1033.8$ $[\mathrm{M}+\mathrm{Na}]^{+}(42)$. HPLC retention time $=13.033 \mathrm{~min}($ System A).

\section{NMR Spectroscopy}

NMR spectra of the two diastereoisomeric peptides were acquired using a Bruker Avance spectrometer operating at a nominal ${ }^{1} \mathrm{H}$ frequency of $500 \mathrm{MHz}$ and equipped with a $5 \mathrm{~mm}$ BBO probe including Z-axis pulse field gradients. Spectra of samples in DMSO were acquired at temperatures between $298 \mathrm{~K}$ and $323 \mathrm{~K}$ in steps of $5 \mathrm{~K}$. Assignments of the ${ }^{1} \mathrm{H}$ spectra were achieved using standard sequential assignment procedures of protein spectra. ${ }^{1} 2 \mathrm{D}\left[{ }^{1} \mathrm{H},{ }^{1} \mathrm{H}\right]$ TOCSY spectra ${ }^{2}$ were acquired employing $60 \mathrm{~ms}$ mixing time and $2 \mathrm{D}\left[{ }^{1} \mathrm{H},{ }^{1} \mathrm{H}\right]$ NOESY spectra ${ }^{3}$ employing mixing times between $100 \mathrm{~ms}$ and $300 \mathrm{~ms}$. All spectra were processed using Bruker NMR Suite 3.5 and Amix Viewer 3.1.5 (Bruker Biospin GMBH). Chemical shifts were referenced to the residual DMSO methyl group signal at $2.5 \mathrm{ppm}\left({ }^{1} \mathrm{H}\right)$. All distance between protons were derived from the $2 \mathrm{D}\left[{ }^{1} \mathrm{H},{ }_{1}^{1} \mathrm{H}\right]$ NOESY spectra at $200 \mathrm{~ms}$, and were grouped into three categories according to relative volumes of cross-peaks. The distance restraints used in the structure calculations were divided into three groups with limits of 1.8-2.8, 1.8-3.8, 1.8-5.0 $\AA$ (an additional $0.5 \AA$ were added to the distance restraints involved methyl groups).

\section{Structure Calculations}

All NMR based calculations were carried out using Macromodel 8.1(Schrödinger, L.L.C.) and OPSLA/AA force field. Conformational search was performed using GB/SA method with water as the solvent and dielectric constant as 1 . For the peptide with the L-configuration at Ade8, 92 distance constraints were included, and for the peptide with the D-configuration, 15 distance constraints were used. A set of 20 lowest energy conformers for each peptide were clustered and presented in Figure S1. 

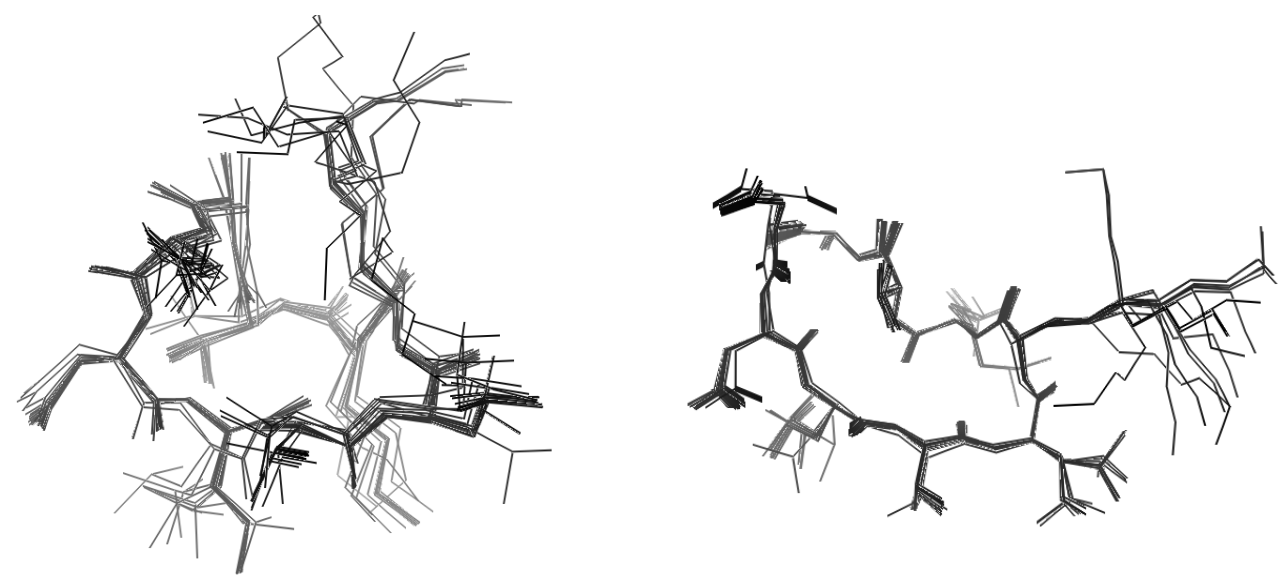

Figure S1. Overlap of 20 lowest energy conformations of $\mathbf{2}$ (left) and $\mathbf{3}$ (right)

\section{Results}

The room temperature spectra of the two peptides were broad, indicating aggregation of the samples. The aggregation of the samples was attributed to the absence of the chromophore, causing different behaviour of these cyclic peptides in comparison to chlorofusin under similar conditions. Temperature experiments were performed for both samples and the set of $2 \mathrm{D}\left[{ }^{1} \mathrm{H},{ }^{1} \mathrm{H}\right]$ spectra (TOCSY and NOESY) were acquired at the lowest temperature that had acceptable resolution and NOE pattern enabling sequential assignment of NOESY spectra. Full sets of spectra of the peptides with the $\mathrm{L}$ - and D-configurations at the Ade8 residue were acquired at $308 \mathrm{~K}$ and $323 \mathrm{~K}$ respectively. The ${ }^{1} \mathrm{H}$ spectra of the two peptides at elevated temperatures show a single set of resonances.

The concentrations were also chosen to minimise the level of aggregation, therefore concentrations for both samples were too low to get good quality ${ }^{13} \mathrm{C}$ or $\mathrm{HMQC}$ spectra to assign ${ }^{13} \mathrm{C}$.

Assignments of 1D and 2D ${ }^{1} \mathrm{H}$ spectra were achieved using standard protein $\left[{ }^{1} \mathrm{H},{ }^{1} \mathrm{H}\right]$ NMR spectra assignments [Wutrich, 1986], and chemical shifts of the two peptides were compared to those chemical shifts of chlorofusin (Table 1). The amide proton chemical shifts of the D-Ade8 peptide are similar to the corresponding chemical shifts of chlorofusin. The absolute differences between shifts are between -0.15 and 0.09 ppm, while the for the L-Ade8 peptide, this range is much larger, between -0.97 and 1.04 (Figure S2). This indicates that the D-Ade8 peptide chain has a similar structure to the peptide chain of chlorofusin, and that the chiral centre at Ade8 has a significant role in the folding of chlorofusin. However, the chemical shift differences of the alpha-protons in D-Ade8 are larger (between -0.19 and 0.35), suggesting that the absence of the chromophore affects the backbone and the conformation of D-Ade8, and that the conformation of the D-Ade8 peptide is not the same as the conformation of the peptide in chlorofusin.

NOE-based distance restraints were derived from the $[1 \mathrm{H}, 1 \mathrm{H}]$ NOESY spectra and used in a conformational search to generate 200 different conformations for both peptides. A superposition of 20 lowest energy structures for both peptides is shown in Fig. S1. The conformations of the backbone peptide chains of both peptides were well defined (RMS $=0.622$ and 0.182 for 2 and 3 respectively), while all heavy atoms, including the side-chains, exhibited higher RMS values (1.18 and 0.776 for 2 and 3 
respectively) due to presence of ambiguous and intermolecular NOE cross-peaks that could not be used in these NMR-based structure calculations.

Table 1. Comparison of assignments of chlorofusin and the two diastereoisomers

\begin{tabular}{|c|c|c|c|c|}
\hline \multirow[t]{2}{*}{ Residue } & \multirow[t]{2}{*}{ Position } & \multicolumn{3}{|l|}{${ }^{1} \mathrm{H}$ chemical shift (ppm) } \\
\hline & & Chlorofusin 1 (293 K) & $2(323 \mathrm{~K})$ & $3(308 \mathrm{~K})$ \\
\hline Thr 1 & $\begin{array}{l}\mathrm{HN} \\
\mathrm{H} \alpha \\
\mathrm{H} \beta \\
\mathrm{H} \gamma \\
\mathrm{OH}\end{array}$ & $\begin{array}{l}8.73(\text { br s) } \\
3.66(\text { br s) } \\
4.02(\mathrm{~m}) \\
1.16(\mathrm{~d}) \\
5.28(\mathrm{br} \mathrm{s})\end{array}$ & $\begin{array}{l}8.58(\mathrm{br} \mathrm{s}) \\
4.10(\mathrm{br} \mathrm{s}) \\
3.74(\mathrm{br} \mathrm{s}) \\
1.20(\mathrm{~d}) \\
5.25(\mathrm{br} \mathrm{s})\end{array}$ & $\begin{array}{l}7.76(\mathrm{br} \mathrm{s}) \\
4.17(\mathrm{~d}) \\
3.96(\mathrm{~m}) \\
1.07(\mathrm{~d}) \\
4.71(\mathrm{~d})\end{array}$ \\
\hline Ala 2 & $\begin{array}{l}\mathrm{HN} \\
\mathrm{H} \alpha \\
\mathrm{H} \beta\end{array}$ & $\begin{array}{l}8.61(\mathrm{~d}) \\
3.95(\mathrm{~m}) \\
1.26(\mathrm{~m})\end{array}$ & $\begin{array}{l}8.53(\mathrm{br} \mathrm{s}) \\
4.03(\mathrm{br} \mathrm{s}) \\
1.31(\mathrm{o} / \mathrm{l})\end{array}$ & $\begin{array}{l}7.85(\mathrm{br} \mathrm{s}) \\
4.20(\mathrm{~m}) \\
1.26(\mathrm{~d})\end{array}$ \\
\hline Asn 3 & $\begin{array}{l}\mathrm{HN} \\
\mathrm{H} \alpha \\
\mathrm{H} \beta \\
\mathrm{H}_{\mathrm{N} 2}\end{array}$ & $\begin{array}{l}6.93(\mathrm{br} \mathrm{s}) \\
4.75(\mathrm{dt}) \\
2.62(\mathrm{dd}) ; 2.93(\mathrm{dd}) \\
6.90(\mathrm{br} \mathrm{s}) ; 6.82(\mathrm{br} \mathrm{s})\end{array}$ & $\begin{array}{l}7.00(\mathrm{br} \mathrm{d}) \\
4.45(\mathrm{br} \mathrm{m}) \\
2.58(\mathrm{o} / \mathrm{l}) ; 2.97(\mathrm{dd})\end{array}$ & $\begin{array}{l}7.72(\mathrm{br} \mathrm{s}) \\
4.49(\mathrm{dt}) \\
2.48(\mathrm{o} / \mathrm{l}) ; 2.60(\mathrm{dd})\end{array}$ \\
\hline D-Asn4 & $\begin{array}{l}\mathrm{HN} \\
\mathrm{H} \alpha \\
\mathrm{H} \beta \\
\mathrm{H}_{\mathrm{N} 2}\end{array}$ & $\begin{array}{l}7.84 \text { (br s) } \\
4.41 \text { (ddd) } \\
2.48(\mathrm{dd}) ; 2.75(\mathrm{dd}) \\
7.00(\mathrm{br} \mathrm{s}) ; 7.24(\mathrm{br} \mathrm{s})\end{array}$ & $\begin{array}{l}7.80(\mathrm{br} \mathrm{d}) \\
4.80(\mathrm{br} \mathrm{m}) \\
2.56(\mathrm{o} / \mathrm{l}) ; 2.75(\mathrm{dd})\end{array}$ & $\begin{array}{l}7.98(\mathrm{br} \mathrm{s}) \\
4.45(\mathrm{q}) \\
2.48(\mathrm{o} / \mathrm{l}) ; 2.60(\mathrm{dd})\end{array}$ \\
\hline D-Leu 5 & $\begin{array}{l}\mathrm{HN} \\
\mathrm{H} \alpha \\
\mathrm{H} \beta \\
\mathrm{H} \gamma \\
\mathrm{H} \delta\end{array}$ & $\begin{array}{l}7.51(\mathrm{~d}) \\
4.48(\mathrm{dt}) \\
1.13(\mathrm{br} \mathrm{m}) ; 1.60(\mathrm{~m}) \\
1.41(\mathrm{~m}) \\
0.77(\mathrm{~d}) ; 0.78(\mathrm{~d})\end{array}$ & $\begin{array}{l}7.54(\mathrm{~d}) \\
4.51(\mathrm{br} \mathrm{t}) \\
1.16(\mathrm{o} / \mathrm{l}) ; 1.62(\mathrm{~m}) \\
1.44(\mathrm{br} \mathrm{m}) \\
0.84(\mathrm{~d}) ; 0.82(\mathrm{~d})\end{array}$ & $\begin{array}{l}7.95(\mathrm{~d}) \\
4.28(\mathrm{br} \mathrm{s}) \\
1.52(\mathrm{~m}) \\
1.52(\mathrm{~m}) \\
0.88(\mathrm{~d}) ; 0.82(\mathrm{~d})\end{array}$ \\
\hline Thr 6 & $\begin{array}{l}\mathrm{HN} \\
\mathrm{H} \alpha \\
\mathrm{H} \beta \\
\mathrm{H} \gamma \\
\mathrm{OH}\end{array}$ & $\begin{array}{l}7.07(\mathrm{~s}) \\
3.92(\mathrm{~m}) \\
3.92(\mathrm{~m}) \\
1.10(\mathrm{~d}) \\
5.05(\mathrm{br} \mathrm{s})\end{array}$ & $\begin{array}{l}7.12(\mathrm{br} \mathrm{s}) \\
3.98(\mathrm{br} \mathrm{s}) \\
3.95(\mathrm{br} \mathrm{s}) \\
1.15(\mathrm{br} \mathrm{d}) \\
4.91(\mathrm{br} \mathrm{s})\end{array}$ & $\begin{array}{l}7.54(\mathrm{~d}) \\
4.17(\mathrm{~m}) \\
3.96(\mathrm{~m}) \\
1.07(\mathrm{~d}) \\
5.10(\mathrm{~d})\end{array}$ \\
\hline D-Leu 7 & $\begin{array}{l}\mathrm{HN} \\
\mathrm{H} \alpha \\
\mathrm{H} \beta \\
\mathrm{H} \gamma \\
\mathrm{H} \delta\end{array}$ & $\begin{array}{l}9.08(\mathrm{br} \mathrm{s}) \\
3.95(\mathrm{~m}) \\
1.60(\mathrm{~m}) \\
1.71-1.88(\mathrm{~m}) \\
0.92(\mathrm{~d}) ; 0.82(\mathrm{~d})\end{array}$ & $\begin{array}{l}8.97(\mathrm{br} \mathrm{s}) \\
3.97(\mathrm{~m}) \\
1.81(\mathrm{~m}) ; 1.64(\mathrm{~m}) \\
1.57(\mathrm{~m}) \\
0.96(\mathrm{~d}) ; 0.88(\mathrm{~d})\end{array}$ & $\begin{array}{l}8.25(\mathrm{br} \mathrm{s}) \\
4.12(\mathrm{~m}) \\
1.51(\mathrm{~m}) \\
1.51(\mathrm{~m}) \\
0.82(\mathrm{~d})\end{array}$ \\
\hline Ade 8 & $\begin{array}{l}\mathrm{HN} \\
\mathrm{H} \alpha \\
\mathrm{H} \beta \\
\mathrm{H} \gamma \\
\mathrm{H} \delta \\
\mathrm{H} \varepsilon \\
\mathrm{H} \zeta \\
\mathrm{H} \eta \\
\mathrm{H} \theta\end{array}$ & $\begin{array}{l}7.70(\mathrm{~d}) \\
4.02(\mathrm{~m}) \\
1.71-1.88(\mathrm{~m}) \\
1.26(\mathrm{br} \mathrm{m}) ; 1.38(\mathrm{~m}) \\
1.26(\mathrm{br} \mathrm{m}) \\
1.26(\mathrm{br} \mathrm{m}) \\
1.26(\mathrm{br} \mathrm{m}) \\
1.26(\mathrm{br} \mathrm{m}) \\
1.26(\mathrm{br} \mathrm{m}) \\
0.87(\mathrm{t})\end{array}$ & $\begin{array}{l}7.73(\mathrm{~d}) \\
4.08(\mathrm{~m}) \\
1.81(\mathrm{~m}) \\
1.42(\mathrm{br} \mathrm{m}) \\
1.37(\mathrm{br} \mathrm{m}) \\
1.31(\mathrm{br} \mathrm{m}) \\
1.31(\mathrm{br} \mathrm{m}) \\
1.31(\mathrm{br} \mathrm{m}) \\
1.31(\mathrm{br} \mathrm{m}) \\
0.90(\mathrm{t})\end{array}$ & $\begin{array}{l}8.00(\mathrm{~d}) \\
4.03(\mathrm{~m}) \\
1.66-1.77(\mathrm{~m}) \\
1.24(\mathrm{br} \mathrm{m}) \\
1.24(\mathrm{br} \mathrm{m}) \\
1.24(\mathrm{br} \mathrm{m}) \\
1.24(\mathrm{br} \mathrm{m}) \\
1.24(\mathrm{br} \mathrm{m}) \\
1.24(\mathrm{br} \mathrm{m}) \\
0.87(\mathrm{t})\end{array}$ \\
\hline Orn 9 & $\begin{array}{l}\mathrm{HN} \\
\mathrm{H} \alpha \\
\mathrm{H} \beta \\
\mathrm{H} \gamma \\
\mathrm{H} \delta\end{array}$ & $\begin{array}{l}6.69(\mathrm{br} \mathrm{s}) \\
4.59(\mathrm{br} \mathrm{t}) \\
1.71-1.88(\mathrm{~m}) \\
1.71-1.88(\mathrm{~m}) \\
3.42(\mathrm{t})\end{array}$ & $\begin{array}{l}6.78(\mathrm{br} \mathrm{s}) \\
4.60(\mathrm{br} \mathrm{t}) \\
1.84(\mathrm{~m}) \\
1.54(\mathrm{~m}) \\
2.82(\mathrm{t})\end{array}$ & $\begin{array}{l}7.73(\mathrm{br} \mathrm{s}) \\
4.30(\mathrm{br} \mathrm{s}) \\
1.82(\mathrm{~m}) \\
1.57-176(\mathrm{~m}) \\
2.82(\mathrm{t})\end{array}$ \\
\hline
\end{tabular}




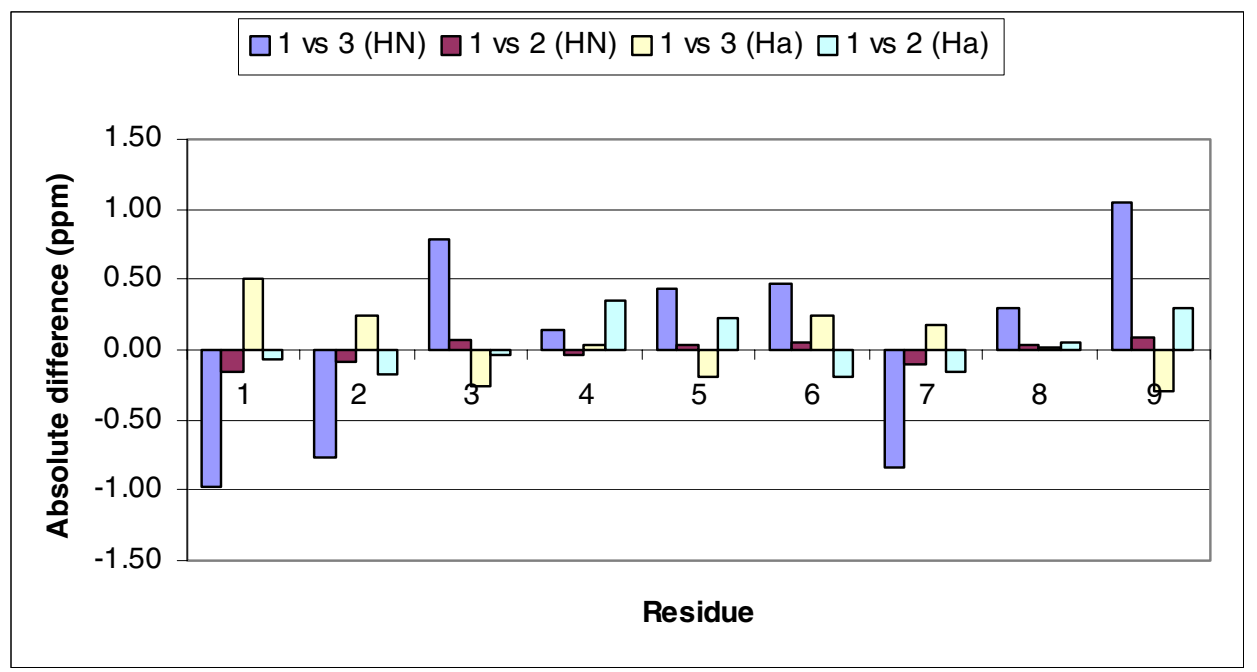

Figure S2. Difference in amide $(\mathrm{HN})$ and alpha $(\mathrm{H} \alpha){ }^{1} \mathrm{H}$ NMR chemical shifts between chlorofusin (1), and the D-Ade8-containing (2) and L-Ade8-containing (3) peptides (DMSO- $d_{6}$, $500 \mathrm{MHz}, 293 \mathrm{~K}, 308 \mathrm{~K}$ and $323 \mathrm{~K}$, respectively)

\section{References}

1. Wüthrich, K. NMR of the Proteins and Nucleic Acids, Wiley: New York, 1986.

2. Bax, A.; Davis, D.G. J. Magn. Reson. 1985, 65, 355-360.

3. Jeener, I.; Meier, BE.HE.; Ernst, BE.P.; Ernst, R.R. J. Chem. Phys. 1979, 71, $4546-4553$. 